\title{
Preparation and immunogenicity of a bivalent cell-surface protein-polysaccharide conjugate of Vibrio cholerae
}

\author{
S. KABIR
}

International Centre for Diarrhoeal Disease Research, Dhaka, Bangladesh

\begin{abstract}
Summary. Alkali-treated lipopolysaccharides (LPS) from Ogawa and Inaba serotypes of Vibrio cholerae were chemically coupled to cell-surface proteins of $V$. cholerae. The reaction product was eluted in the void volume when fractionated on a column of Sephacryl S-300. The material did not enter the gel when subjected to polyacrylamide gel electrophoresis in the presence of sodium dodecyl sulphate (SDS-PAGE). The bivalent protein-polysaccharide conjugate was nonpyrogenic, as determined by the Limulus lysate assay. It was immunogenic and elicited, in rabbits, antibodies against both intact LPS and cell surface proteins, as determined by enzyme linked immunosorbent assay. LPS from Ogawa serotype was resolved into two major bands by SDS-PAGE and that from the Inaba serotype into one major band. Immunoblotting studies indicated that antisera to the protein-polysaccharide conjugate contained antibodies to the major LPS fractions from both serotypes. Antisera to the proteinpolysaccharide conjugate tested by crossed-immunoelectrophoresis produced immunoprecipitation with whole-cell sonicates of both biotypes and serotypes of $V$. cholerae. Such antisera also possessed agglutinating and complement-mediated bactericidal activities towards $V$. cholerae strains of both biotypes and serotypes. These results suggest that a bivalent cell-surface protein-polysaccharide conjugate of $V$. cholerae could be developed as a nonpyrogenic vaccine against cholera.
\end{abstract}

\section{Introduction}

Vibrio cholerae is a non-invasive pathogen that colonises the small intestine. There it secretes an enterotoxin which is regarded as the cause of choleral diarrhoea (De and Chatterje, 1953). Although immune responses to cell-wall antigens and secreted toxin moieties develop in the host, volunteer studies have shown that the main immune mechanism is antibacterial rather than antitoxic (Levine et al., 1979).

The outer membrane of $V$. cholerae contains proteins and lipopolysaccharides (LPS) that are immunogenic in man (Majumdar et al., 1981; Kabir, 1983a). Results from field trials indicate that $V$. cholerae LPS can offer protection against cholera (Mosley et al., 1970). However, $V$. cholerae LPS is highly pyrogenic and is not suitable for immunisation against cholera. $V$. cholerae has two serotypes (Ogawa and Inaba) and two biotypes (classical and

Correspondence should be sent to: Dr S. Kabir, Tobaksspinnargatan $5 \mathrm{nb}, 11736$ Stockholm, Sweden.

Received 4 Mar. 1986; accepted 30 Apr. 1986
El Tor). The serological specificities amongst these types are determined by the LPS molecules, and the covalently linked lipid A part of LPS contributes to endotoxic properties (Raziuddin, 1978). The cellsurface proteins representing the common antigens of $V$. cholerae are nontoxic (Kabir, 1980, 1983 $a$ and $b$; Kabir and Mann, 1980). Although toxic properties of the LPS can be reduced by treatment with alkali, the resulting alkali-treated LPS are poor immunogens, as has been found with LPS from other gram-negative bacteria (Whang et al., 1971; Sadoff et al., 1982). However, immunogenicity can be enhanced by chemically coupling the alkalitreated LPS to carrier proteins.

Infections with $V$. cholerae are common in several regions of the world and thousands of cases of cholera are reported each year to the World Health Organization (1983). Vaccines currently used for prophylactic immunisation against cholera consist of equal numbers of Ogawa and Inaba serotypes (Joó, 1974). These vaccines induce adverse reactions in many recipients (Feeley, 1970; Schrader, 1975; Mall and Gyr, 1984). Therefore, there is a 
need for a safe cholera vaccine for human use. The present investigation was initiated to prepare a bivalent, cell-surface protein-polysaccharide conjugate of $V$. cholerae.

\section{Materials and methods}

\section{Bacteria and growth conditions}

Vibrio cholerae strains 395 (Ogawa, classical), 569B (Inaba, classical), W-13021 (Ogawa, El Tor) and W28419 (Inaba, El Tor) were used in the study. Cultures were grown in peptone-water $3 \% \mathrm{w} / \mathrm{v}$ with continuous shaking at $37^{\circ} \mathrm{C}$ for $12 \mathrm{~h}$ and were harvested in stationary phase.

\section{Isolation of LPS}

LPS was prepared from $V$. cholerae strains 395 (Ogawa, classical) and 569B (Inaba, classical) by the phenol-water procedure described by Westphal et al. (1952). Crude LPS was further purified to remove proteins and nucleic acids by a procedure involving repeated ultracentrifugation at $105000 \mathrm{~g}$ (Westphal and Jann, 1965).

\section{Preparation of the alkali-treated LPS}

LPS $(50 \mathrm{mg}$ ) was incubated with sodium hydroxide $(0.17 \mathrm{~N}, 100 \mathrm{ml})$ at $56^{\circ} \mathrm{C}$ for $1 \mathrm{~h}$. The mixture was centrifuged at $5000 \mathrm{~g}$ for $15 \mathrm{~min}$. The supernate was adjusted to $p \mathrm{H} 7.0$ by neutralisation with acetic acid ( $1 \mathrm{~N})$ and was poured on to 4 volumes of cold ethanol $(95 \%)$. The precipitated polysaccharide was recovered by centrifugation, resuspended in $50 \mathrm{ml}$ of water and lyophilised (35 mg).

\section{Extraction of cell-surface proteins of $V$. cholerae}

A 10-g (wet weight) samples of $V$. cholerae 395 (Ogawa) was washed twice with cold $0 \cdot 1 \mathrm{M} \mathrm{NaCl}$ and extracted with cold EDTA/ $\mathrm{NaCl}(25 \mathrm{ml} 0.12 \mathrm{M}$ EDTA plus $0.77 \mathrm{M} \mathrm{NaCl}$,


$g, 30 \mathrm{~min}$ ) and concentrated by negative pressure dialysis. EDTA was removed by dialysis against $0.01 \mathrm{~m}$ phosphate-

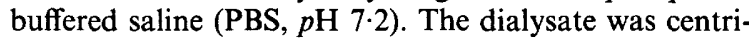
fuged at $10000 \mathrm{~g}$ for $15 \mathrm{~min}$ and the resulting supernate was used for further investigation.

\section{Chemical coupling of cell-surface proteins to alkali- treated LPS}

Equal amounts $(25 \mathrm{mg})$ of alkali-treated LPS of two serotypes were dissolved in water $(20 \mathrm{ml})$ and mixed with a freshly prepared solution of cyanogen bromide $(0.2 \mathrm{ml}$, $50 \mathrm{~g} / \mathrm{l} ;$ Sigma). The $p \mathrm{H}$ of the reaction was kept constant at 11.0 by drop-by-drop addition of $0.2 \mathrm{~N} \mathrm{NaOH}$. Cellsurface proteins $(25 \mathrm{mg})$ were suspended in $0.1 \mathrm{M}$
$\mathrm{NaHCO}_{3}$ and were added to the activated LPS. The mixture was tumbled overnight at $4^{\circ} \mathrm{C}$ and then centrifuged at $10000 \mathrm{~g}$ for $10 \mathrm{~min}$. The supernate was dialysed against distilled water and lyophilised.

\section{Gel filtration of the protein-polysaccharide conjugate}

The material resulting from the coupling reaction was resuspended in $5 \mathrm{ml}$ of $0.12 \mathrm{M} \mathrm{Tris}-\mathrm{HCl}, p \mathrm{H} 8.0$, containing sodium deoxycholate $0.5 \% \mathrm{w} / \mathrm{v}$, and was passed through a Sephacryl S-300 column $(1.5 \times 90 \mathrm{~cm})$ eluted with the same buffer. The void volume fractions were pooled and concentrated by ultrafiltration. As a control, cell surface proteins were also analysed by gel filtration under identical conditions.

\section{Polyacrylamide gel electrophoresis}

The procedure of King and Laemmli (1971) was used. The gel $(10 \% \mathrm{w} / \mathrm{v})$ was cast between two plates $(15 \times 15$ $\mathrm{cm}$ ) to a height of $10 \mathrm{~cm}$, with spacers $1.5 \mathrm{~mm}$ thick. A stacking gel (acrylamide $3 \% \mathrm{w} / \mathrm{v}) 2 \mathrm{~cm}$ high was applied on top of the analytical gel. Electrophoresis proceeded at $30 \mathrm{~mA}$ until the tracking dye reached the end of the analytical gel. Bovine serum albumin, mol. wt 66000 , ovalbumin, mol. wt 45000 , and trypsinogen, mol. wt 24000 , were used as marker proteins. The gel was stained for proteins with Coomassie Brilliant Blue R250.

Individual LPS preparations (1 $\mathrm{mg}$ ) were dissolved in 1 $\mathrm{ml}$ of sample buffer containing $50 \mathrm{~mm}$ Tris- $\mathrm{HCl}, p \mathrm{H} 6.8$, SDS $2 \% \mathrm{w} / \mathrm{v}$, glycerol $10 \% \mathrm{v} / \mathrm{v}$ and bromophenol blue $0.01 \% \mathrm{w} / \mathrm{v}$. Slab gels were stained for carbohydrate moieties by the periodic acid-schiff (PAS) reagent as described by Zacharius et al. (1969).

\section{Electrophoretic transfer of LPS from polyacrylamide gels to nitrocellulose sheets}

LPS was transferred electrophoretically from polyacrylamide gels to a nitrocellulose sheet at $25 \mathrm{~V}$ for $18 \mathrm{~h}$ in a solution containing $25 \mathrm{~mm}$ Tris, $192 \mathrm{~mm}$ glycine, methanol $20 \% \mathrm{v} / \mathrm{v}$ and SDS $0.1 \% \mathrm{w} / \mathrm{v}$. The $p \mathrm{H}$ of the solution was $8 \cdot 3$. The blot was then soaked in bovine serum albumin $3 \% \mathrm{w} / \mathrm{v}$ in Tween buffer which consisted of a mixture of $\mathrm{NaCl} 0.9 \% \mathrm{w} / \mathrm{v}, 10 \mathrm{~mm}$ Tris- $\mathrm{HCl}, p \mathrm{H} \mathrm{7.4,155}$ $\mathrm{mM} \mathrm{NaCl}$ and Tween $200.5 \% \mathrm{w} / \mathrm{v}$. It was then incubated for $1 \mathrm{~h}$ with $5 \mathrm{ml}$ of antiserum to the protein-polysaccharide conjugate diluted 1 in 100 in Tween buffer. The blot was washed extensively with Tween buffer, incubated for $1 \mathrm{~h}$ with horseradish peroxidase-conjugated $\mathrm{IgG}$ preparations and washed again as described above. The colour was developed by soaking the blot in a solution containing: dioctyl sodium sulphosuccinate $0 \cdot 2 \%$, tetramethylbenzidine $0.06 \%, \mathrm{H}_{2} \mathrm{O}_{2} 0.02 \% \mathrm{v} / \mathrm{v}, 5 \mathrm{mM}$ citric acid, $10 \mathrm{mM}$ $\mathrm{Na}_{2} \mathrm{HPO}_{4}, p \mathrm{H} \mathrm{5 \cdot 0}$. The reaction was terminated after 5 min by washing with water. 


\section{Preparation of $V$. cholerae sonicates}

$V$. cholerae cultures $(200 \mathrm{ml})$ were grown in $3 \% \mathrm{w} / \mathrm{v}$ peptone water in $1-\mathrm{L}$ bottles at $37^{\circ} \mathrm{C}$ with shaking to an absorbance at $600 \mathrm{~nm}$ of $0.8-1.0$ and harvested by centrifugation at $10000 \mathrm{~g}$ for $10 \mathrm{~min}$ at $4^{\circ} \mathrm{C}$. The cell pellet was suspended in $10 \mathrm{ml}$ of PBS $(0.01 \mathrm{M}, p \mathrm{H} \mathrm{7.4)}$ and was sonicated in an ultrasonicator (Branson Sonic, Danbury, CT, USA). The process was continued for $10 \mathrm{~min}$ (1 $\mathrm{min}$ sonication alternately with $1 \mathrm{~min}$ cooling in ice). The sonicate had an optical density $<1 \%$ of the starting suspension. Unbroken cells were removed by centrifugation at $10000 \mathrm{~g}$ for $10 \mathrm{~min}$. The supernate was further concentrated by dialysis in colloidion bags against polyethylene glycol $40 \% \mathrm{w} / \mathrm{v}$ to a final volume of $1 \mathrm{ml}$.

\section{Antisera}

To obtain immune sera, New Zealand white rabbits about 8 weeks old $(2-3 \mathrm{~kg})$ were immunised intramuscularly with $1 \mathrm{mg}$ of either protein-polysaccharide conjugate or alkali-treated LPS. Both preparations were suspended in an emulsion of $0.5 \mathrm{ml}$ of PBS plus $0.5 \mathrm{ml}$ of Freund's Complete adjuvant.

\section{Crossed immunoelectrophoresis}

Crossed immunoelectrophoresis with an intermediate gel was performed according to the procedures described by Weeke (1973) and Axelsen (1973). A 10-ml solution of molten agarose $1 \% \mathrm{w} / \mathrm{v}$ containing polyethylene glycol $60001 \% \mathrm{w} / \mathrm{v}$ was poured on to a warmed glass plate $(8 \times 12 \times 0.1 \mathrm{~cm})$ on a horizontal table. $V$. cholerae sonicates $(7 \mu \mathrm{l})$ were applied to a well $(3 \mathrm{~mm}$ diameter). Electrophoresis in the first dimension was performed on the gel plate at $10 \mathrm{~V} / \mathrm{cm}$ and was monitored by placing $7 \mu \mathrm{l}$ of $0.01 \%$ bromophenol blue in one of the wells.

A strip of the gel containing test material $(1.8 \times 8 \times 0 \cdot 1$ $\mathrm{cm}$ ) was placed on the hydrophilic side of Gel Bond film (Marine Colloids). An intermediate gel $(2 \times 8 \times 0.1 \mathrm{~cm})$ was interposed between the first dimension gel and the second dimension gel containing antibody molecules. Solutions $(4 \mathrm{ml}$ of agarose $1 \% \mathrm{w} / \mathrm{v})$ containing $0.25 \mu \mathrm{l}$ of the immune sera were placed on the remainder of the gel. Electrophoresis was performed at $2 \mathrm{~V} / \mathrm{cm}$ on the gel plate

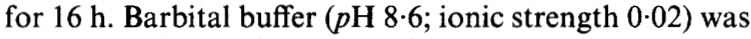
used for electrophoresis. Afterwards the gels were washed, dried, stained and destained as described by Weeke (1973).

\section{Enzyme linked immunosorbent assay (ELISA)}

Comparative serum antibody levels to LPS and cellsurface proteins were determined by ELISA in microtitration plates. Plates were coated with optimal doses of the antigens, determined in preliminary experiments. Cellsurface proteins and LPS were used at $50 \mu \mathrm{g} / \mathrm{ml}$ and $20 \mu \mathrm{g} /$ $\mathrm{ml}$ respectively. Five-fold dilutions of the test sera obtained 2 weeks after boosting were added to the antigen-coated wells and incubated at $37^{\circ} \mathrm{C}$ for $2 \mathrm{~h}$. After washing, the wells were filled with sheep anti-rabbit immunoglobulin-conjugated peroxidase (specific for rabbit $\operatorname{IgG}$ and $\operatorname{IgA}$ ). After incubation for $2 \mathrm{~h}$ at $37^{\circ} \mathrm{C}$, the plates were washed and incubated for a further $10 \mathrm{~min}$ with the substrate consisting of tetramethylbenzidine in dimethyl sulphoxide and hydrogen peroxide. The reaction was stopped by the addition of $1 \mathrm{~N} \mathrm{H}_{2} \mathrm{SO}_{4}$ and the absorbance was measured at $450 \mathrm{~nm}$ by a Titertek Multiskan automatic plate reader (Flow Laboratories, McLean, VA, USA).

\section{Serum vibriocidal assay}

Serial fivefold dilutions of heat inactivated antiserum were made in a $0.5-\mathrm{ml}$ volume containing $0.4 \mathrm{ml}$ of fresh guinea-pig complement. To each dilution was added 0.45 $\mathrm{ml}$ of a bacterial suspension containing $2 \times 10^{3}$ viable $V$. cholerae cells $/ \mathrm{ml}$. The mixture was incubated at $37^{\circ} \mathrm{C}$ for 1 $\mathrm{h}$ and plated on nutrient agar. Colonies of $V$. cholerae were counted after overnight incubation at $37^{\circ} \mathrm{C}$. The vibriocidal titre was determined as the dilution of serum that caused $50 \%$ inhibition of bacterial growth.

\section{Bacterial agglutination}

Bacterial cultures were adjusted to $10^{13}$ cells $/ \mathrm{L}$ in $0 \cdot 2 \mathrm{M}$


polysaccharide-protein conjugate that had previously been heated at $56^{\circ} \mathrm{C}$ for $30 \mathrm{~min}$ were added to an equal volume of bacteria in microtitration plates. The agglutination pattern was recorded after incubation for $2 \mathrm{~h}$ at room temperature.

\section{Proton magnetic spectroscopy (p.m.r.)}

${ }^{1} \mathrm{H}$-p.m.r. spectra were recorded on a $200 \mathrm{MHz}$ spectrometer (Varian, Palo Alto, CA, USA). The alkalitreated LPS was thrice lyophilised from $99 \cdot 7 \% \mathrm{D}_{2} \mathrm{O}$ and examined in the same solvent. The chemical shifts were expressed relative to external sodium 4,4-dimethyl-4silapentane-1-sulphonate.

\section{Limulus amoebocyte lysate test}

The endotoxin contents of the LPS and the proteinpolysaccharide conjugate were determined by the Limulus amoebocyte lysate test in a flat-bottomed microtitration plate as described by Kreeftenberg et al. (1977).

\section{Electronmicroscopy}

$V$. cholerae cells, after extraction with EDTA/ $\mathrm{NaCl}$, were fixed in glutaraldehyde $2 \%$ in $0 \cdot 1 \mathrm{M}$ sodium cacodylate buffer $(p \mathrm{H} 7)$ containing $0 \cdot 1 \mathrm{~m}$ sucrose for 1 week. The samples were then centrifuged, and the pellets were suspended in distilled water. One drop from the sample was applied to a carbon-coated grid. A $2 \% \mathrm{w} / \mathrm{v}$ solution of sodium silicotungstate was applied to a carbon-coated grid. The grids were rinsed with several drops of sodium 
silicotungstate $2 \%$ in water. The specimens were examined in an electronmicroscope (Philips EM 200, Philips Electronic Instruments, Mahwah, NJ, USA) operated at $60 \mathrm{kV}$.

\section{Results}

The composition of the EDTA-extracted material of $V$. cholerae

The extraction of $V$. cholerae with EDTA/ $\mathrm{NaCl}$ was monitored by electronmicroscopy. No cell lysis was observed. The polar flagellum of $V$. cholerae remained intact. The extracted material was predominantly protein $(90 \%$, by weight) and its composition was analysed by SDS-PAGE (fig. 1). The major component had an approximate mol. wt of 48000 . In addition, prominent protein bands of approximate mol. wts $66000,25000,20000$ and 13000 were observed.

The electrophoretic mobilities of $V$. cholerae LPS

The LPS and alkali-treated LPS from both

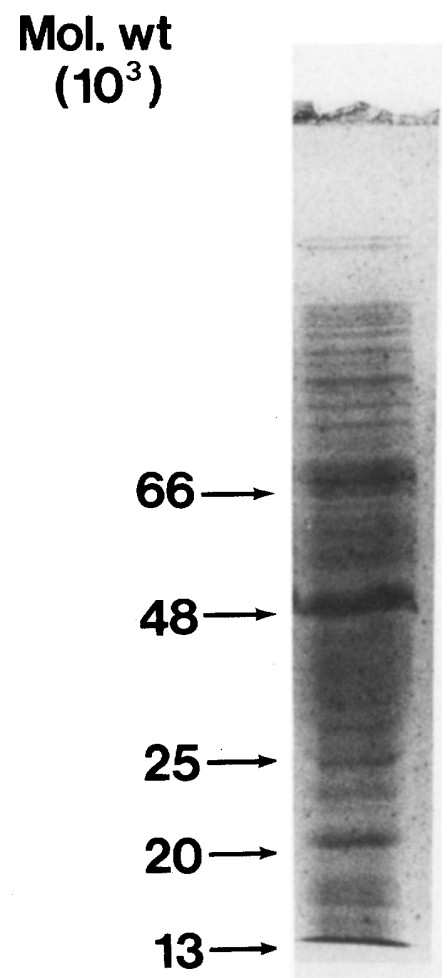

Fig. 1. Composition of the cell surface proteins of $V$. cholerae strain 395 (Ogawa, classical) by SDS-PAGE.

\section{a $\quad$ b $\quad c \quad d$}

(1)


serotypes of $V$. cholerae were analysed by polyacrylamide gel electrophoresis (fig. 2). Ogawa LPS produced a slow migrating and a fast migrating band. Inaba LPS produced one thick band with a mobility close to that of the fast migrating band of Ogawa LPA.

Ester-linked fatty acids (Kabir, 1982) were removed by treating the LPS with $0 \cdot 17 \mathrm{~N}$ sodium hydroxide at $56^{\circ} \mathrm{C}$ for $1 \mathrm{~h}$. The extent of deacylation was monitored by p.m.r. The characteristic proton chemical shifts of ester groups which occur at 2-2.2 ppm (Solomons, 1976) were absent from the ${ }^{3} \mathrm{H}-$ p.m.r. spectra of the alkali-treated LPS. The alkalitreated $V$. cholerae LPS was readily soluble in water in contrast to the native LPS. Treatment with alkali had little effect upon the electrophoretic mobility (fig. 2).

\section{Covalent coupling of alkali-treated LPS to cell surface proteins}

The product resulting from the coupling reaction was subjected to gel chromatography and eluted in the void volume (fig. 3). It was subjected to SDSPAGE and did not enter the gel (fig. 3) suggesting that a chemical bond was formed between carbohydrate and protein moieties. Because the upper limit of mol. wt for molecules entering the gel is $c$. $2 \times 10^{6}$, it is most likely that the material was heavily cross-linked.

\section{Limulus lysate reactivity}

Both Ogawa and Inaba LPS possessed endotoxicity as judged by gelation of the Limulus lysate. The minimum concentrations were $0.015 \mathrm{ng} / \mathrm{ml}$ and 0.25 $\mathrm{ng} / \mathrm{ml}$ for Inaba and Ogawa LPS respectively. The protein-polysaccharide conjugate, even when used at a concentration of $200 \mu \mathrm{g} / \mathrm{ml}$, had essentially no activity in the Limulus assay.

\section{Immunological studies on the conjugate}

To investigate whether immune sera to proteinpolysaccharide conjugate contained any antibody to $V$. cholerae LPS and if so, against which compo-



Fig. 3. Gel filtration of the bivalent polysaccharide-protein conjugate and cell-surface proteins of $V$. cholerae 395 on a Sephacryl S300 column $(1.5 \times 90 \mathrm{~cm})$ eluted with Tris- $\mathrm{HCl}(0.12 \mathrm{M}, \mathrm{pH} 8 \cdot 0)$ containing sodium deoxycholate $0.5 \% \mathrm{w} / \mathrm{v} ;$ flow rate $20 \mathrm{ml} / \mathrm{h}, 5-\mathrm{ml}$ fractions were collected; - polysaccharide-protein conjugate, $-\triangle$ cell surface proteins of $V$. cholerae 395 . SDS-PAGE of the bivalent polysaccharide-protein conjugate and a mixture of standard proteins is shown in the inset on the left. (a) Polysaccharideprotein conjugate purified by gel chromatography; (b) a mixture of bovine serum albumin (mol. wt $66 \times 10^{3}$ ), ovalbumin (mol. wt $45 \times 10^{3}$ ) and trypsinogen (mol. wt $24 \times 10^{3}$ ). 




Fig. 4. Immunoblot reactivity of antisera to the polysaccharideprotein conjugate to $V$. cholerae LPS; $5 \mu \mathrm{g}$ of $V$. cholerae LPS, separated by SDS-PAGE, were transferred electrophoretically to a nitrocellulose membrane and the blot developed by ELISA. (a) LPS from $V$. cholerae 569B (Inaba); (b) LPS from $V$, cholerae 395 (Ogawa).

nents, LPS blotting studies were performed. Both Ogawa and Inaba LPS reacted with antiserum to the protein-polysaccharide conjugate (fig. 4). Ogawa LPS produced two bands, one fast and one slow migrating, the latter being densely stained. The Inaba LPS produced a broad and diffuse band which migrated close to the fast moving LPS band. A few slow moving minor bands were detected in the Inaba LPS blot. No reaction was observed when the blot was incubated with preimmune sera.

The electrophoretic patterns among various $V$. cholerae sonicates were similar (fig. 5), suggesting that the conjugate contained several common antigens of $V$. cholerae irrespective of their sero and biotypes.

In ELISA tests, antibodies of both IgG and IgA isotypes to both the LPS and the carrier cell-surface proteins were detected in the immune sera (fig. 6). Highest antibody titre was obtained to cell-surface proteins. Alkali-treated LPS was poorly immunogenic; very little antibody level was detected in sera. However, when alkali-treated LPS was covalently coupled to cell-surface proteins, antibody titres to polysaccharide moieties were greatly enhanced.

The antisera agglutinated $V$. cholerae strains of both biotypes and both serotypes (fig. 7). The antisera also possessed complement-dependent bactericidal activity against $V$. cholerae strains of all types.

\section{Discussion}

A new immunogenic and nonpyrogenic proteinpolysaccharide conjugate of $V$. cholerae was produced by chemically coupling alkali-treated LPS from Ogawa and Inaba serotypes to cell surface proteins of $V$. cholerae. $V$. cholerae LPS contains neutral and acidic sugars (Redmond, 1978; Sen et al., 1979; Kabir, 1982). The endotoxic lipid A component can be removed from the LPS by acid hydrolysis (Raziuddin, 1978; Kabir, 1982). However, acid hydrolysis will destroy highly acidsensitive sugars such as 4-amino-arabinose. In the present study mild alkaline conditions were used to detoxify $V$. cholerae LPS which contains several fatty acids of which only one is amide linked. The remaining ester-linked fatty acids were removed by mild treatment with alkali (Kabir, 1982). The resulting deacylated LPS was soluble in aqueous medium and did not respond in the Limulus lysate assay. Thus, mild alkaline treatment renders the deacylated LPS nonpyrogenic without the risk of losing acid labile components such as 4-aminoarabinose.

Cell-surface proteins of $V$. cholerae can be obtained with EDTA/NaCl extraction (Kabir, 1983b). These surface proteins were chemically coupled by cyanogen bromide activation to alkalitreated LPS from Ogawa and Inaba serotypes. Because the polysaccharide moiety of $V$. cholerae LPS contains primary amino, free hydroxylic and carboxylic groups (Redmond, 1978; Kabir, 1982), these groups may have been involved in the direct attack of cyanogen bromide on carbohydrates to form covalent linkages with the amino groups of proteins. 

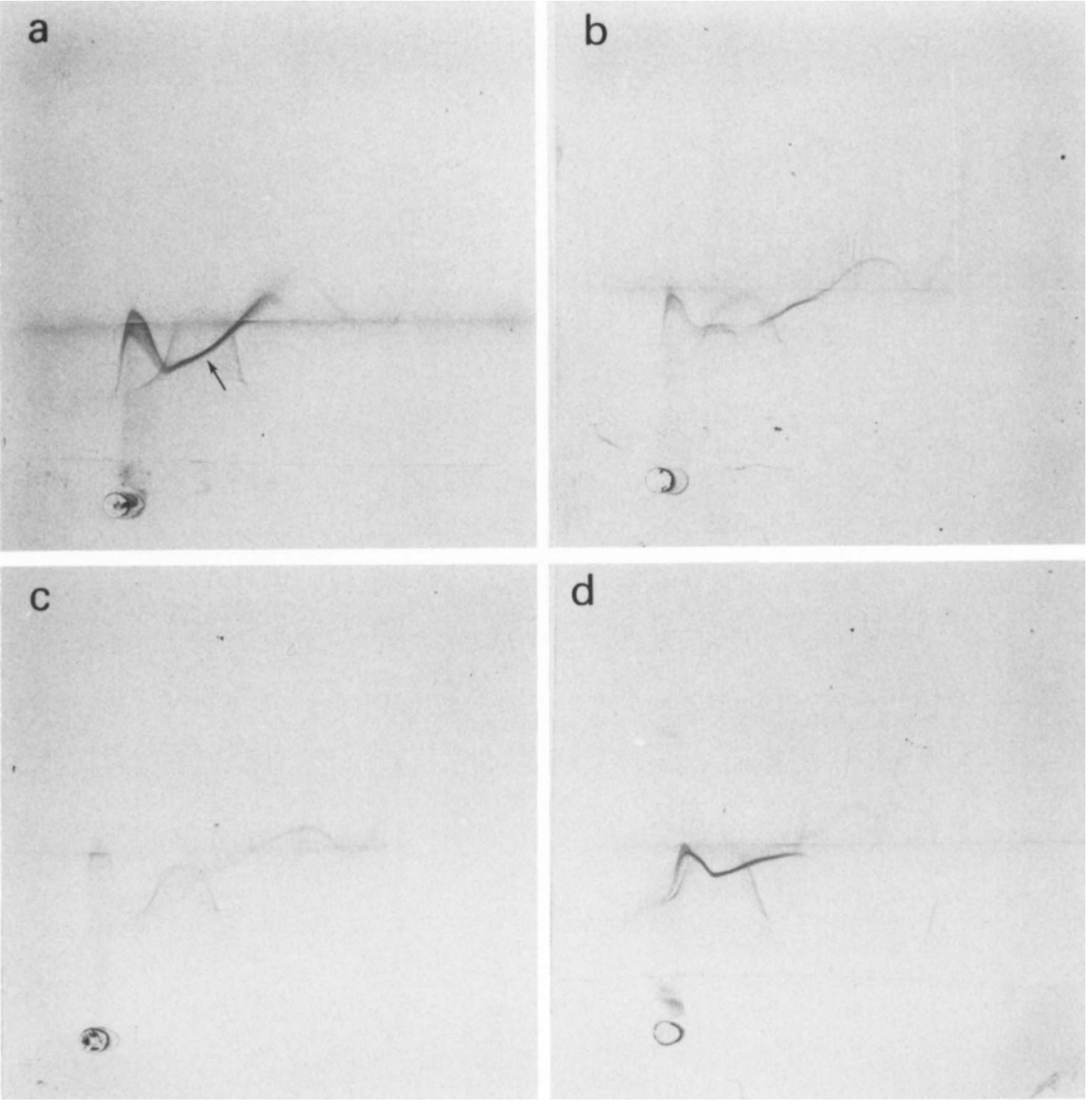

Fig. 5. Analysis of $V$. cholerae sonicates by crossed immunoelectrophoresis. An intermediate gel was interposed between the firstdimension gel and the second dimension gel to facilitate the recognition of precipitates at the base line. The second dimension gel contained immune rabbit sera against the polysaccharide-protein conjugate of $V$. cholerae. The precipitation line due to the polysaccharide, as shown by an arrow in (a), was detected by staining the gel with the periodic-schiff reagent (Zacharius et al., 1969). (a) V. cholera 395 (Ogawa, classical); (b) 569B (Inaba, classical); (c) W-28419 (Inaba, El Tor); (d) W-13021 (Ogawa, El Tor).

Several lines of evidence suggest that a conjugate of protein-polysaccharide was formed: first, the conjugate was eluted in the void volume of the column containing Sephacryl S-300 which has mol.wt exclusion limits of $1.5 \times 10^{6}$ and $4.0 \times 10^{5}$ for proteins and polysaccharides respectively. Proteins, not subjected to the conjugation reaction, were eluted separately and in the inclusion volume of the column. Second, when the conjugate was subjected to SDS-PAGE, it did not enter the gel. Third, alkalitreated LPS itself was poorly immunogenic (fig. 6). In contrast, high-titre antibodies to both Ogawa and Inaba LPS were detected when rabbits were immunised with the conjugate. This indicates that the polysaccharide moieties were part of the same molecule that contained both protein and polysaccharide moieties in the form of a covalently linked hapten-carrier complex. 


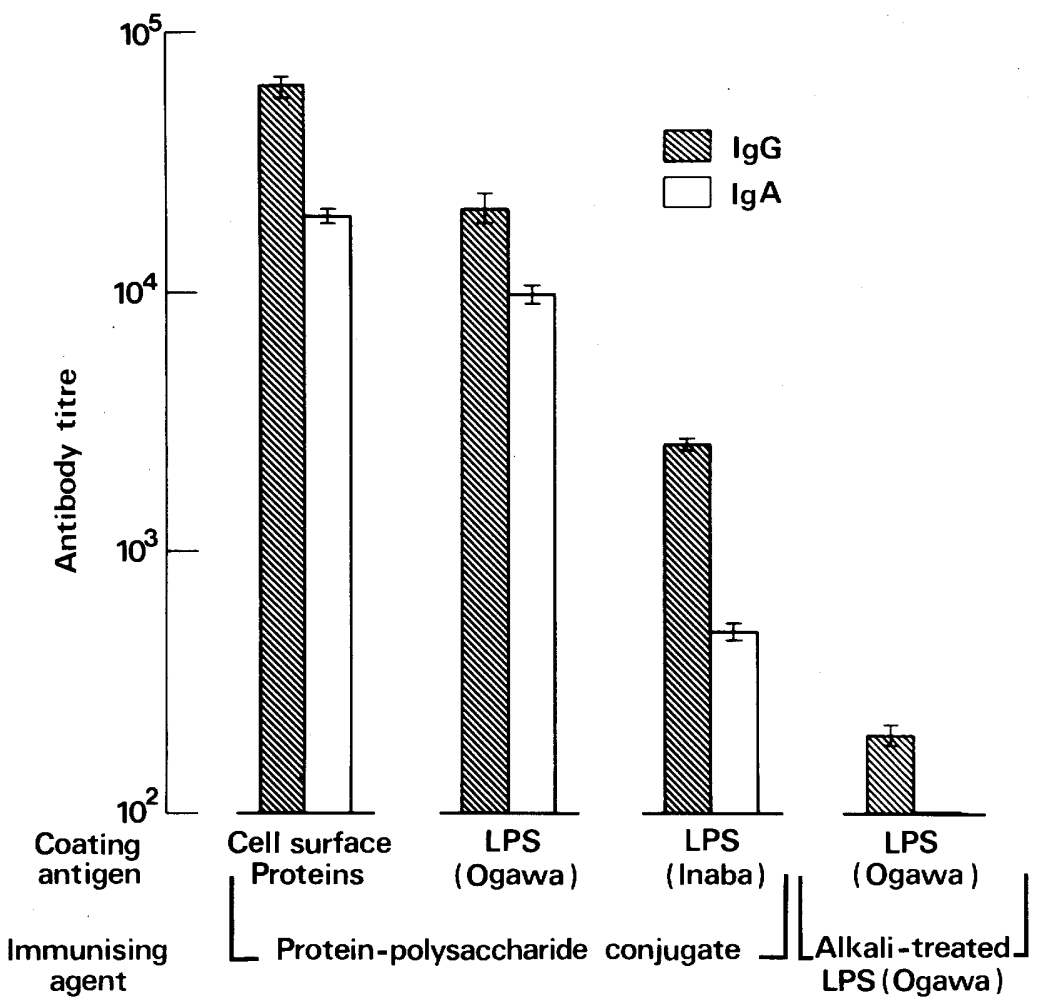

Fig. 6. Comparative IgG and IgA responses in sera of rabbits immunised with cell-surface protein-polysaccharide conjugate and alkali-treated LPS. Rabbits were given the protein-polysaccharide conjugate $(1 \mathrm{mg} /$ dose) or alkali-treated LPS (1 mg/dose) by intramuscular injection as described in the text. Test sera were collected from two rabbits 2 weeks after booster doses. ELISA was performed in microtitration plates. Absorbance readings at $450 \mathrm{~nm}>0.1$ were considered positive. Each value represented the arithmetic mean of three readings.

A

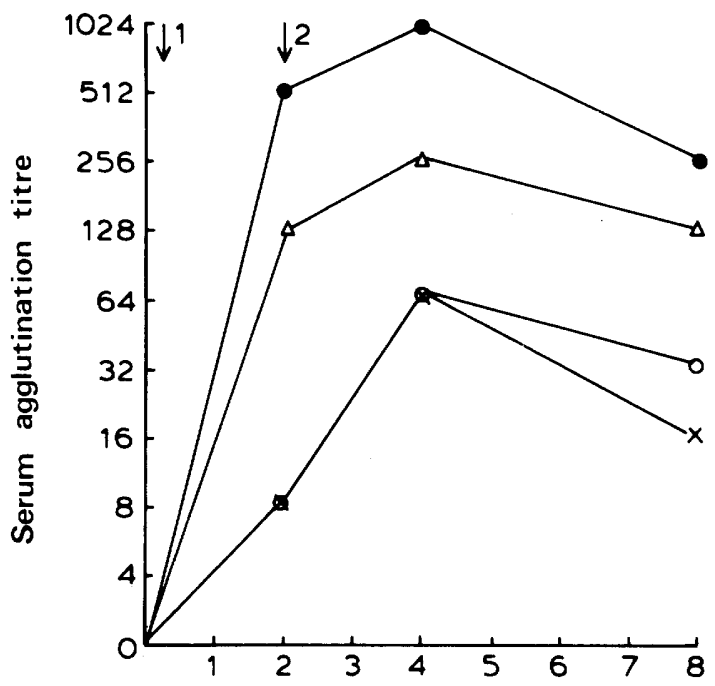

Time after first injection (weeks)
B

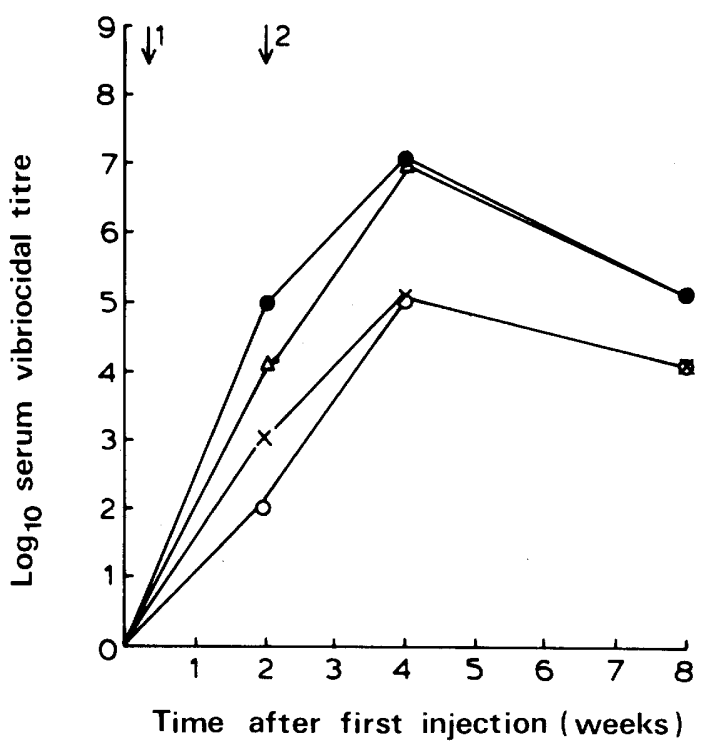

Fig. 7. The kinetics of appearance of (A) agglutinating and (B) bactericidal antibodies in rabbit sera after immunisation with the protein-polysaccharide conjugate. Arrows $(\uparrow)$ indicate the time of priming doses (1) and boosting doses (2) given to two rabbits. The following strains were used: 395 (๑-Ogawa, classical), W-13021 ( $\triangle$ - Ogawa, El Tor), 569B (O-Inaba, classical) and W-28419 ( $\times$ Inaba, El Tor). 
The electrophoretic pattern of the Ogawa LPS on the polyacrylamide gel differed from that of the Inaba LPS. The presence of two LPS bands in the Ogawa serotype indicated that the LPS was heterogeneous and contained a mixture of both slow moving (smooth) and fast migrating (rough) LPS. Polyacrylamide gel electrophoresis has been applied to study electrophoretic patterns of rough and smooth LPS from gram-negative bacteria such as salmonellae and Escherichia coli (Kabir, 1976; Goldman and Leive, 1980). It has been observed that LPS from rough bacterial strains possessing shorter O-specific side chains migrates faster during electrophoresis.

The antibody titre to Inaba LPS in sera raised against the protein-polysaccharide conjugate was less than that to Ogawa LPS. This might be due to lower immunogenicity of Inaba LPS because of its shorter chain length. Conjugate antisera contained immunoglobulins to the polysaccharide fractions from $V$. cholerae Ogawa and Inaba serotypes. Both the polysaccharide fractions of the Ogawa serotype were detected in nitrocellulose blots. The Inaba blot showed a few minor bands which might have been due to the contaminating proteins associated with LPS.

The electrophoretic patterns of alkali-treated LPS did not differ from those of untreated LPS indicating that the removal of ester-linked fatty acids did not affect the electrophoretic mobilities of the polysaccharide moieties of the LPS. Because intact LPS preparations used in the immunoblot technique reacted with antisera to the proteinpolysaccharide conjugate, it is evident that the antigenic determinants that bound anti-LPS antibodies remained intact in the conjugate. Thus alkaline treatment and subsequent chemical coupling did not affect the antigenic determinants of native LPS.

The protein-polysaccharide conjugate gave negative results in the Limulus test which detects $0.01-$

\section{REFERENCES}

Axelsen N H 1973 Intermediate gel in crossed and in fused rocket immunoelectrophoresis. Scandinavian Journal of Immunology 2 Suppl no. 1: 71-77.

De S N, Chatterje D N 1953 An experimental study of the mechanism of action of Vibrio cholerae on the intestinal mucous membrane. Journal of Pathology and Bacteriology 66:559-562.

Feeley J C 1970 Cholera vaccines. In: Principles and practice of cholera control (WHO Public Health Papers no. 40). World Health Organization, Geneva, pp 87-93.
$0.1 \mathrm{ng}$ of enterobacterial endotoxin $/ \mathrm{ml}$. The Limulus test is much more sensitive than the rabbit pyrogen assay which detects 1-10 ng of endotoxin and is now widely used to detect pyrogens from gram-negative bacteria in controlling the quality of vaccines (Kreeftenberg et al., 1977; Marcus and Nelson, 1977).

$V$. cholerae LPS is highly immunogenic (Kabir, 1982), but mild alkaline treatment greatly reduced that property. Similar observations have been made with LPS from other gram-negative bacteria (Whang et al., 1971). The immunogenicity of the alkali-treated $V$. cholerae LPS was greatly enhanced by covalently coupling to a protein carrier. Such an approach to enhance the immunogenicity of alkalitreated LPS has been adopted with Pseudomonas aeruginosa LPS (Sadoff et al., 1982).

The protein-polysaccharide conjugate contained several antigens common to both the biotypes and serotypes of $V$. cholerae. The conjugate produced both IgG and IgA antibodies reactive with cellsurface proteins and intact LPS. The antisera possessed both agglutinating and bactericidal activities against $V$. cholerae strains of both biotypes and both serotypes. These results. suggest that the protein-polysaccharide could be a non-pyrogenic candidate vaccine against cholera. It may also be possible to prepare a purely synthetic cholera vaccine by chemically coupling immunodominant regions of $V$. cholerae LPS with immunogenic domains of the outer-membrane proteins of $V$. cholerae.

I thank Drs E. J. Ruitenberg and P. A. M. Guinée (National Institute of Public Health, Bilthoven, The Netherlands) for ELISA and immunoblotting studies, Dr P. Askelof (The National Bacteriological Laboratory, Stockholm, Sweden) for electronmicroscopy and Dr F. Brewer (Albert Einstein College of Medicine, New York) for proton magnetic resonance studies.
Goldman R C, Leive L 1980 Heterogeneity of antigenic-sidechain length in lipopolysaccharide from Escherichia coli 0111 and Salmonella typhimurium LT2. European Journal of Biochemistry 107:145-153.

Joó I 1974 Cholera vaccines. In: Barua D, Burrows W (eds) Cholera. W .B. Saunders Co., Philadelphia, pp 333-355.

Kabir S 1976 Electrophoretic studies of smooth and rough Salmonella lipopolysaccharides on polyacrylamide gels. Microbios Letters 1:79-85.

Kabir S 1980 Composition and immunochemical properties of outer membrane proteins of Vibrio cholerae. Journal of Bacteriology 144:382-389. 
Kabir S 1982 Characterization of the lipopolysaccharide from Vibrio cholerae 395 (Ogawa). Infection and Immunity 38:1263-1272.

Kabir S $1983 a$ Immunochemical properties of the major outer membrane protein of Vibrio cholerae. Infection and Immunity 39:452-455.

Kabir S $1983 b$ The serological properties of the cell surface proteins of Vibrio cholerae. Journal of General Microbiology 129:2199-2206.

Kabir S, Mann P 1980 Immunological properties of the cell envelope components of Vibrio cholerae. Journal of General Microbiology 119:517-525.

King J, Laemmli U K 1971 Polypeptides of the tail fibres of bacteriophage T4. Journal of Molecular Biology 62:465-477.

Kreeftenberg J G, Loggen H G, van Ramshoorst, J D, Beuvery E C 1977 The Limulus amoebocyte lysate test: micromethod and application in the control of sera and vaccines. Developments in Biological Standardization 34:15-20.

Levine M M et al. 1979 Immunity to cholera in man: relative role of antibacterial versus antitoxic immunity. Transactions of the Royal Society of Tropical Medicine and Hygiene 73:3-9.

Majumdar A S, Dutta P, Dutta D, Ghose A C 1981 Antibacterial and antitoxin responses in the serum and milk of cholera patients. Infection and Immunity 32:1-8.

Mall T, Gyr K 1984 Episode resembling immune complex disease after cholera vaccination. Transactions of the Royal Society of Tropical Medicine and Hygiene 78:106-107.

Marcus S, Nelson J R 1977 Tests alternative to the rabbit bioassay for pyrogens. Developments in Biological Standardization 34:45-55.

Mosley W H et al. 1970 The 1968-1969 cholera-vaccine field trials in rural East Pakistan. Effectiveness of monovalent Ogawa and Inaba vaccines and a purified Inaba antigen, with comparative results of serological and animal protection tests. Journal of Infectious Diseases 121(Suppl):1-9.

Raziuddin S 1978 Toxic and immunological properties of the lipopolysaccharides (O-antigens) from Vibrio el tor. Immunochemistry 15:611-614.

Redmond J W 1978 The 4-amino sugars present in the lipopolysaccharides of Vibrio cholerae and related vibrios. Biochimica et Biophysica Acta 542:378-384.

Sadoff J C, Futrovsky S L, Sideberry H F, Iglewski B H, Seid R C 1982 Detoxified lipopolysaccharide-protein conjugates. In: Robbins J B et al. (eds) Bacterial vaccines (Seminars in infectious Diseases 4). Thieme-Stratton, New York, pp 346354.

Schrader H 1975 Ein Fall von Guillain Barré-Syndrome nach cholera-schutzimpfung. Journal of Neurology 209:69-74.

Sen A K, Mukherjee A K, Guhathakurta B, Dutta A, Sasmal D 1979 Structural investigations on the lipopolysaccharide isolated from Vibrio cholerae Inaba 569B. Carbohydrate Research 72:191-199.

Solomons T W G 1976 Organic Chemistry, John Wiley, London, p 512.

Weeke B 1973 Crossed immunoelectrophoresis. Scandinavian Journal of Immunology 2 Suppl 1:47-56.

Westphal O, Lüderitz O, Bister F 1952 Uber die Extraktion von Bakterien mit Phenol-wasser. Zeitschrift für Naturforschung Teil B 7:148-155.

Westphal O, Jann K 1965 Bacterial lipopolysaccharides. Extraction with phenol-water and further applications of the procedure. Methods in Carbohydrate Chemistry 5:83-91.

Whang H Y, Mayer H, Neter E 1971 Differential effects on immunogenicity and antigenicity of heat, freezing and alkali treatment of bacterial antigens. Journal of Immunology 106:1552-1558.

World Health Organization 1983 Cholera 1963-1982. In: World health statistics annual. World Health Organization, Geneva, pp 787-790.

Zacharius R M, Zell T E, Morrison J H, Woodlock J J 1969 Glycoprotein staining following electrophoresis on acrylamide gels. Analytical Biochemistry 30:148-152. 